\title{
Spatial genetic structure of Simarouba amara Aubl. (Simaroubaceae), a dioecious, animal-dispersed Neotropical tree, on Barro Colorado Island, Panama
}

\author{
BD Hardesty ${ }^{1,2}$, CW Dick ${ }^{1,4}$, A Kremer ${ }^{3}$, S Hubbell ${ }^{1,2}$ and E Bermingham ${ }^{1}$ \\ ${ }^{1}$ Smithsonian Tropical Research Institute, Unit 0948, APO AA 34002-0948, USA; ${ }^{2}$ Plant Biology Department, University of Georgia, \\ Athens, Georgia 30605, USA; ${ }^{3} I N R A$ Station de Recherches Forestieres, Laboratoire de Génétique des Arbres Forestiers BP45 33611 \\ Gazinet Cedex, France; ${ }^{4}$ Department of Ecology and Evolution, Herbarium, University of Michigan, Ann Arbor, MI 48109-1048, USA
}

\begin{abstract}
Simarouba amara (Simaroubaceae) is a vertebrate-dispersed, insect-pollinated Neotropical tree found in lowland moist forest from upper Mesoamerica to the Amazon basin. We assessed the spatial genetic structure of $S$. amara within the 50-ha Forest Dynamics Plot on Barro Colorado Island in the Republic of Panama. A total of 300 individuals were genotyped using five microsatellite loci, representing 100 individuals with a $\mathrm{dbh} \geqslant 10 \mathrm{~cm}, 100$ individuals of $1-10 \mathrm{~cm} \mathrm{dbh}$, and 100 individuals of $<1 \mathrm{~cm} \mathrm{dbh}$. The 200 individuals in the two larger size classes were also genotyped with 155 AFLP loci. Spatial autocorrelation
\end{abstract}

analysis using Moran's Index detected significant genotypic association at the smallest distance classes for $1-10 \mathrm{~cm}$ dbh $(0-20 \mathrm{~m})$ and $>10 \mathrm{~cm} \mathrm{dbh}(0-40 \mathrm{~m})$ size categories. Significant spatial autocorrelations were detected over larger scales $(0-140 \mathrm{~m})$ in $<1 \mathrm{~cm} d b h$ individuals. The relatively weak genetic structure of $S$. amara, in comparison to other recent studies, may be explained by pollen and seed dispersal over the 50 ha plot, overlapping seed shadows, and postrecruitment mortality.

Heredity (2005) 95, 290-297. doi:10.1038/sj.hdy.6800714; published online 10 August 2005

Keywords: AFLP; dispersal; spatial genetic structure; microsatellites; tropical forest

\section{Introduction}

Tropical forest tree species tend to exhibit spatially clumped distributions (Hubbell, 1979; Hubbell and Foster, 1983; Condit et al, 2000), while having low numbers of conspecific individuals per unit area. Spatially limited seed dispersal contributes to the patterns of clumping. However, in comparisons between tropical and temperate zone trees, it is unclear whether tropical trees experience greater dispersal limitation due to their preponderant reliance on animals for both pollination and seed dispersal (Bawa, 1990). Moreover, it is difficult to predict patterns of gene flow in tropical trees because of the unpredictable effect of animal behavior on gene movement (Nason and Hamrick, 1997; Hamrick and Loveless, 1986). Models of gene flow for tropical forest trees require either (1) direct observation of pollinator movements or seed dispersal agents (Webb and Bawa, 1983; Howe, 1986; Schupp, 1993; Boshier et al, 1995); (2) indirect estimates based on $\mathrm{F}_{\mathrm{St}^{-}}$ based statistics or spatial autocorrelation (Hamrick et al, 1993; Hamilton and Miller, 2002; Dick et al, 2003; Vekemans and Hardy, 2004); or (3) use of genetic markers to reconstruct seed and pollen movement through

Correspondence: BD Hardesty, Department of Plant Biology, University of Georgia, 2502 Miller Plant Sciences, Athens, GA 30602, USA.

E-mail: hardesty@plantbio.uga.edu

Received 21 December 2004; accepted 13 June 2005; published online 10 August 2005 parentage analyses (Aldrich and Hamrick, 1998; Ouborg et al, 1999; Jordano and Godoy, 2002; Sezen et al, 2005). Here we contribute to an emerging body of data on spatial genetic structure in tropical trees through an analysis of spatial genetic structure of the tropical tree Simarouba amara within the 50-ha Forest Dynamics Plot (FDP) on Barro Colorado Island (BCI), Panama where we have two decades of demographic data based on periodic censuses of all $S$. amara $\geqslant 1 \mathrm{~cm}$ diameter at breast height (dbh).

The specific objectives of our study were: (1) to describe the genetic diversity of a mapped population of $S$. amara within a lowland Neotropical forest using microsatellite and AFLP data; (2) to evaluate the genetic structure of three size classes of individuals ( $>10,1-10$, and $<1 \mathrm{~cm} \mathrm{dbh}$ ) at the 50 ha scale; and (3) to assess the level of heterozygosity across those three size classes. If seed dispersal and pollen movement is limited, our prediction is increased genetic relatedness among individuals in close proximity. However, if effective seed dispersal is widespread relative to the distance between reproductive individuals, or if there is extensive overlap of seed shadows, the result should be a lack of detected spatial genetic structure.

\section{Materials and methods}

\section{Study species}

S. amara Aubl. (Simaroubaceae) is a widespread Neotropical tree species found in lowland moist forests from 
upper Mesoamerica (Honduras, Nicaragua) across the lower rim of the Amazon basin (Bolivia and Peru) eastward to French Guiana. The wood of S. amara is used locally for paper, furniture building, interior construction, plywood, and matches (Rodriguez von Platen, 2000). S. amara is dioecious, insect pollinated, and dispersed primarily by vertebrates (birds and large mammals). It grows to $35 \mathrm{~m}$ in height with a maximum reported diameter at breast height (dbh) on BCI of $70 \mathrm{~cm}$ (Croat, 1978). S. amara requires intermediate to high light environments, and on BCI typically flowers from the end of January through April. The unisexual flowers of $S$. amara occur in terminal panicles comprised of numerous, small ( $<1 \mathrm{~cm}$ long), pale yellowish flowers. Data from 15 years reporting all flowering and fruiting parts arriving in seed traps suggest that there is overlap in the phenology of $S$. amara adults (SJ Wright, unpublished data). Flowering persists for approximately 11-15 weeks annually within the 50 ha plot. The floral syndrome of $S$. amara is typical of pollination by generalist small insects such as small bees and moths (Bawa, 1990), which have been observed visiting the flowers of this species (BDH pers. obs.).

Ripe fruits are produced within 1-3 months after pollination. The fruits are large-seeded and fleshy, approximately $17 \mathrm{~mm}$ in length, with a seed of $10_{-}$ $14 \mathrm{~mm}$, and are presented in clusters of 3-5 drupes (Croat, 1978). Seeds of $S$. amara do not experience dormancy. Primates and birds are the primary dispersers of $S$. amara. The brightly colored green to purplish-black fruits attract chacalacas, flycatchers, motmots, and thrushes (Duke as cited in Croat, 1978), as well as howler and spider monkeys (Hladik and Hladik, 1969) and tamarins (BDH pers. obs). Leaf-cutter ants have been observed to carry the seeds, and dense seedling carpets of $S$. amara have been noted only at the two leaf-cutter ant dump sites in the 50 ha FDP (BDH pers. obs).

The year 2000 BCI plot census contained 1230 S. amara individuals $\geqslant 1 \mathrm{~cm}$. The FDP contains 126 individuals $\geqslant 20 \mathrm{~cm} \mathrm{dbh}$, which represents the minimum reproduc- tive size, although most individuals do not reproduce below $30 \mathrm{~cm} \mathrm{dbh}(N=72$ individuals $\geqslant 30 \mathrm{~cm} \mathrm{dbh})$. A total of 48 female trees have been reproductive during the past 3 years according to our observations. Trees flower and fruit annually, though not every reproductive female produces fruit each year (Hardesty, unpubl. data). The mean dispersal distance for $S$. amara seeds is $39 \mathrm{~m}$ based on maximum likelihood best-fit estimates ('inverse modeling') of arrival in seed traps using known distances from reproductive-sized adults within the FDP (Muller-Landau, 2001). Current inverse models do not take tree gender into consideration, however, and likely underestimate seed dispersal distances.

\section{Study site}

This research was carried out in the 50 ha permanent FDP within the Barro Colorado National Monument $\left(9^{\circ} 10^{\prime} \mathrm{N}, 79^{\circ} 51^{\prime} \mathrm{W}\right)$, Republic of Panama. The FDP is located on a plateau near the center of BCI, an island formed by the flooding of Lake Gatun following the construction of the Panama Canal in the early 1900s. The lowland moist tropical forest on BCI receives approximately $2600 \mathrm{~mm}$ of rainfall annually, and the island has a pronounced dry season between December and April (Leigh, 1982). Approximately every 5 years beginning in 1982, all freestanding woody plants within the FDP with $\geqslant 1 \mathrm{~cm}$ diameter breast height $(\mathrm{dbh})$ are identified, mapped, and measured to assess growth, mortality, and recruitment of new individuals.

\section{Sampling strategy}

Using the FDP inventory data, we randomly selected 200 S. amara individuals from two size classes: (1) $1-10 \mathrm{~cm} \mathrm{dbh}(N=100)$, and $(2)>10 \mathrm{~cm} \mathrm{dbh}(N=100)$ (Figure 1). This was carried out by assigning a random number to each tagged individual, then selecting the top 100 numbers in each category after sorting them in ascending order. In order to assess fine level spatial structure below the $1 \mathrm{~cm} \mathrm{dbh}$ class, we performed an

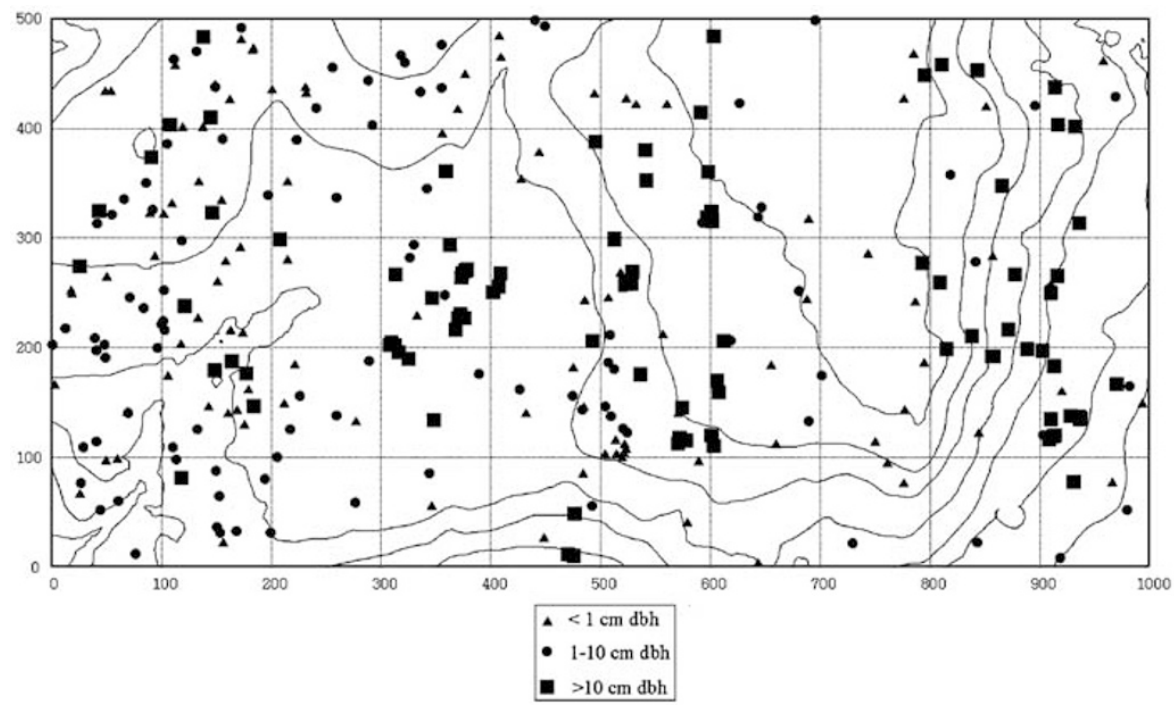

Figure 1 The 50 ha permanent Forest Dynamics Plot on Barro Colorado Island, with 300 S. amara randomly chosen for this study. Locations of 100 individuals of $<1 \mathrm{~cm} \mathrm{dbh}$ are represented with triangles, 100 individuals with a dbh of $1-10 \mathrm{~cm}$ are represented with circles, and 100 individuals with a dbh $>10 \mathrm{~cm}$ are depicted with squares. 
additional sample of 100 'seedlings' that were randomly selected from approximately 500 individuals with $<1 \mathrm{~cm}$ dbh that had been collected in a survey across nearly 40 ha of the FDP. Tissue was collected only from healthy plants in which there was sufficient leaf material such that removal of tissue would be unlikely to cause mortality. In patches of high density $\left(>1\right.$ seedling $\left./ \mathrm{m}^{2}\right)$, tissue from every fourth plant was collected, whereas in lower density areas, tissue was collected from each small plant encountered.

\section{Leaf collection and DNA extraction}

Leaves were collected directly from branches or by using a sling-shot to drop leaves from the canopy of tall trees. The fresh tissue was placed in plastic bags in a cooler with ice while in the field. In the laboratory, samples were either refrigerated and the DNA extracted within 2 days, or they were put into labeled vials and flash-frozen in liquid nitrogen. DNA extractions using $40-50 \mathrm{mg}$ of the fresh tissue were performed using DNEasy ${ }^{\mathrm{TM}}$ kits (Qiagen Corporation).

\section{Microsatellite and AFLP genotyping}

Microsatellite protocol: We tested 11 of the 18 published microsatellite primers for S. amara (Rodriguez von Platen et al, 2000), but poor or unreliable PCR amplification promoted use of the following five dye-labeled primer pairs: SA02 (TET), SA05 (FAM), SA06 (FAM), SA27 (HEX), and SA29 (FAM) (Rodriguez von Platen et al, 2000). The PCR (10.0 $\mu$ l total) contained $250 \mu \mathrm{m}$ of dNTPs, $25 \mu \mathrm{M} \mathrm{MgCl}, 0.0625 \mu \mathrm{l}$ of Taq polymerase (Qiagen Corporation), and $0.5 \mu \mathrm{l}$ of the forward and reverse primer $(10 \mu \mathrm{M}$ stock). All PCRs were performed on an MJ Research PTC-200 thermal cycler, using the following protocol: $5 \mathrm{~min}$ at $94^{\circ} \mathrm{C}$; 25 cycles of $45 \mathrm{~s}$ at $94^{\circ} \mathrm{C}, 1 \mathrm{~min}$ at $53^{\circ} \mathrm{C}$, and $30 \mathrm{~s}$ at $72^{\circ} \mathrm{C}$; ending with $15 \mathrm{~min}$ at $72^{\circ} \mathrm{C}$. Amplification products were electrophoresed using Rox 400 size standard (Applied Biosystems Incorporated, $\mathrm{ABI}$ ) on an MJ Research Base Station Automated DNA Analyzer. Forward primers were labeled with the same fluorescent dyes (HEX, FAM, or TET) on loci with nonoverlapping size ranges to permit loading of all five loci in a single lane.

AFLP protocol: For amplified fragment length polymorphisms, we used a protocol modified from Gadeul et al (2000): digestion and ligation $(11.0 \mu \mathrm{l}$ total volume): $1.1 \mu \mathrm{l}$ of $\mathrm{T} 4$ Buffer $10 \times ; 1.1 \mu \mathrm{l}$ of $0.5 \mathrm{M} \mathrm{NaCl} ; 0.5 \mu \mathrm{l}$ BSA; $1 \mathrm{mg} / \mathrm{ml}$ MseI (1 U) $0.1 \mu \mathrm{l} ;$ EcoRI (5U) $0.25 \mu \mathrm{l}$; T4-Ligase (1.2U) $0.2 \mu \mathrm{l} ;$ MseI Adaptors $1.0 \mu \mathrm{l} ;$ EcoRI Adaptors $1.0 \mu \mathrm{l} ; \mathrm{ddH}_{2} \mathrm{O} \quad 0.2 \mu \mathrm{l}$. In total, $5.5 \mu \mathrm{l}$ of $\geqslant 10 \mathrm{mg} / \mu \mathrm{l}$ DNA was added and the reaction was incubated for $2 \mathrm{~h}$ at $37^{\circ} \mathrm{C}$.

Preselective PCR (total volume $25 \mu \mathrm{l}$ ): We used $14.9 \mu \mathrm{l}$ $\mathrm{ddH}_{2} \mathrm{O}, 2.5 \mu \mathrm{l} 10 \times$ buffer; $1.5 \mu \mathrm{MgCl}_{2} ; 2.0 \mu \mathrm{l}$ of $25 \mu \mathrm{M}$ dNTPs; $0.5 \mu \mathrm{l}$ of $10 \mu \mathrm{M}$ EcoRI (E/A); $0.5 \mu \mathrm{l}$ of $10 \mu \mathrm{M}$ MseI (M/C); $0.1 \mu \mathrm{l}$ Qiagen Taq; and $3.0 \mu \mathrm{l}$ of digested and diluted (1:10) DNA. The PCR was performed for $2 \mathrm{~min}$ at $72^{\circ} \mathrm{C}$; 25 cycles of $30 \mathrm{~s}$ at $94^{\circ} \mathrm{C}, 1 \mathrm{~min}$ at $56^{\circ} \mathrm{C}$, and $30 \mathrm{~s}$ at $72^{\circ} \mathrm{C}$; ending with $10 \mathrm{~min}$ at $72^{\circ} \mathrm{C}$.

Selective PCR $(12.5 \mu \mathrm{l}$ reaction volume) required: $1.25 \mu \mathrm{l}$ of $15 \mathrm{mM} \mathrm{MgCl} 210 \times$ Buffer; $0.5 \mu \mathrm{l} 25 \mathrm{mM} \mathrm{MgCl}_{2} ; 1.0 \mu \mathrm{l}$ of $25 \mathrm{mM}$ dNTPs; $10 \mu \mathrm{M} 0.05 \mu \mathrm{l}$ EcoRI (E-AC or $-\mathrm{ATG}$ );
$0.25 \mu \mathrm{l}$ MseI (M-CTG or -CTT); $0.1 \mu \mathrm{l}$ Hotstart Taq; $0.1 \mu \mathrm{l}$

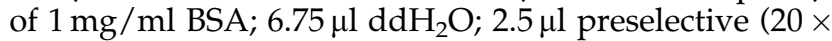
dilution) DNA. The PCR was performed for $15 \mathrm{~min}$ at $95^{\circ} \mathrm{C}$; 13 cycles of $30 \mathrm{~s}$ at $94^{\circ} \mathrm{C}, 1 \mathrm{~min}$ at $65-55.9^{\circ} \mathrm{C}, 1 \mathrm{~min}$ at $72^{\circ} \mathrm{C}\left(\Delta T=-0.7^{\circ} \mathrm{C} /\right.$ cycle $) ; 23$ cycles of $30 \mathrm{~s}$ at $94^{\circ} \mathrm{C}$, $30 \mathrm{~s}$ at $56^{\circ} \mathrm{C}, 1 \mathrm{~min}$ at $72^{\circ} \mathrm{C}$; ending with $15 \mathrm{~min}$ at $72^{\circ} \mathrm{C}$. Two primer pairs were used for AFLP analyses: Mse $1+$ $\mathrm{AC} / E c o R 1+/ \mathrm{CTG}$ and Mse1 + ATG/EcoR1 + CTT. Amplification products were electrophoresed and analyzed using the same equipment and software described for microsatellites.

\section{Data analyses}

Control individuals were run on different gels to insure consistency between gel runs and to evaluate possible base pair shifts that might result in allele assignment errors for both microsatellite and AFLP data. For the microsatellite and AFLP loci, we had $<1$ and $3 \%$ error rates, respectively, in allele assignment for the 200 individuals genotyped using both techniques, comparing individuals run on multiple gels at all loci. Each of the five microsatellite loci was scored using the program Cartographer (MJ Research), utilizing locus binning rules to avoid scoring stutter bands or erroneous alleles. Cervus assignment software (v. 2.0; Marshall et al, 1998) was used to calculate the number of effective alleles, observed and expected heterozygosity, frequency of null alleles, and exclusion probabilities at each locus with knowledge of one parent. GENEPOP (v. 3.3; Raymond and Rousset, 1995) was used to calculate $F_{\text {is }}$ according to Weir and Cockerham (1984), and departure from HardyWeinberg equilibrium was tested using Haldane's exact test (1954), with exact $P$-values estimated using the Markov chain method. Alleles were permuted among individuals within cohorts. We used 1000 random permutation, and jackknifing was performed over loci to estimate standard errors. We used one-way ANOVA and Student's $t$-test to compare allelic richness among the size classes, and $z$-test to compare $H_{\mathrm{o}}$ and $H_{\mathrm{e}}$ among cohorts.

AFLP bands were scored using Cartographer. After scoring, data were transformed to a 1-0 presence/ absence matrix using the program CoTrix (Degen, 1999). We also hand-scored all bands. To ensure consistency, bands with less than $10 \%$ of the average peak height were not included in analyses. In CoTrix, the fragment data are first sorted by length. The user then determines bounds for each fragment length category using a measure of 'coarseness', whereby fragments differ in length by the number of base pairs selected by the programmer. If coarseness is set too low, the possibility of assigning different lengths to identical fragments increases due to variation in electrophoretic mobility across gels, whereas setting coarseness too high may result in the assignment of fragments of different length to the same band class (Degen, 1999). We set the band coarseness at 1.4 base pair differences possibly erring on the conservative side of false locus assignment, and we excluded individuals with fewer than 30 bands, under the assumption that these samples had amplified poorly.

After generating a presence-absence matrix for AFLP bands or tabulating microsatellite alleles, data were analyzed for the existence of spatial autocorrelation 
using SGS (Degen et al, 2001b). In SGS, the significance values are verified using permutation tests $(n=1000)$ based on Monte-Carlo simulation to evaluate deviation from a spatially random distribution of each calculated measure (Manly, 1997), against the null hypothesis of no spatial structure. Simulations compared observed values with the distribution obtained after permutations for each distance class using an individual's AFLP or microsatellite profile. SGS uses the Euclidean distance between pairs of data points. Distograms presenting the Tanimoto distance for AFLP's (Gregorius, 1978), and correlograms using Moran's Index of spatial autocorrelation for microsatellite data (Sokal and Wartenberg, 1983) between all pairs of individuals within an assigned spatial distance class, are plotted against the distance class. At least 30 pairs of individuals must be present at each distance class to ensure statistical robustness (Legendre and Fortin, 1989). At small distance intervals (eg $<20 \mathrm{~m}$ ), fewer than 30 pairs of individuals occur. Thus, our study focuses on $20 \mathrm{~m}$ distance classes. Due to insufficient number of $<1 \mathrm{~cm}$ dbh pairs of individuals at some of the further distance classes, we restricted the seedling analyses to distances $\leqslant 640 \mathrm{~m}$. We used the program SGS (Degen et al, 2001b) to calculate an aggregation index based on Clark and Evans's index $(R)$ (Ripley, 1981) for each size class to determine the pattern of spatial distribution of $S$. amara individuals. Values of $R<1$ indicate an aggregated distribution, $R=1$ signifies random distribution, while $R>1$ is associated with regularly spaced individuals.

\section{Results}

The five polymorphic microsatellite loci ranged in observed heterozygosity between 0.12 and $0.75\left(H_{\mathrm{e}}\right.$ range $=0.33-0.72) \quad($ Table 1$)$. Of the 50 alleles scored, eight $(16.7 \%)$ were rare, occurring in less than $1 \%$ of the individuals genotyped. In total, 12 alleles were 'private alleles, occurring in only one cohort, with 5, 4, and 3 alleles occurring solely at the seedling, 1-10 and $>10 \mathrm{~cm}$ dbh size classes, respectively. The presence of null alleles at locus SA06 is considered probable based on estimates using Cervus (Table 1). The mean numbers of alleles per cohort ranged from 7.6 to 8.2 and were not significantly different (ANOVA, $P>0.05$ ). Mean observed and expected heterozygosities $\left(H_{\mathrm{o}}\right.$ and $\left.H_{\mathrm{e}}\right)$ ranged from 0.502 to $0.524\left(H_{\mathrm{o}}\right)$ and 0.556 to $0.564\left(H_{\mathrm{e}}\right)$ (Table 1$)$ and did not differ among cohorts ( $z$-test, $P>0.05)$.

Significant deviation from Hardy-Weinberg equilibrium was detected at multiple loci in each of the three cohorts, though it was most frequent at the smallest size class, occurring at four of the five loci (Table 1). The fixation index $\left(\mathrm{F}_{\text {is }}\right)$ was most pronounced at SA06 in all cohorts, perhaps because of putative null alleles at that locus. While there was a significant heterozygote deficit for each size category (Table 1), there was no significant difference in the magnitude of the multi-locus $\mathrm{F}_{\text {is }}$ among size categories.

The mean number of AFLP loci per primer per individual was 43.9 (range $=26-71$ loci) excluding individuals that failed to amplify. In total, we analyzed 155 AFLP loci for 190 individuals. No genetic structure was detected at short distances for the pooled population of $S$. amara 1-10 and $>10 \mathrm{~cm} \mathrm{dbh}$ genotyped using AFLP's (not shown), though using microsatellites, structure was evident to $20 \mathrm{~m}$.

When size categories were analyzed separately using Moran's Index, spatial autocorrelation was significant for the $>10 \mathrm{~cm}$ and $1-10 \mathrm{~cm}$ dbh size classes from 0 to 40 and 0 to $20 \mathrm{~m}$, respectively (Figure $2 \mathrm{a}$ and $\mathrm{b}$ ). AFLP analysis

Table 1 Summary table for profiles of microsatellite loci of $S$. amara on BCI, with number of alleles $(k)$, number of effective alleles $\left(A_{\mathrm{e}}\right)$, observed heterozygosity $\left(H_{\mathrm{o}}\right)$, expected heterozygosity $\left(H_{\mathrm{e}}\right)$, and null allele frequency (Null) calculated by the program Cervus (Marshall et al, 1998).

\begin{tabular}{|c|c|c|c|c|c|c|c|c|}
\hline Locus & $\mathrm{k}$ & $\mathrm{A}_{e}$ & $\mathrm{H}_{o}$ & $\mathrm{H}_{e}$ & Null & $P A$ & $\mathrm{~F}_{\text {is }}$ & P-value \\
\hline \multicolumn{9}{|l|}{$<1 \mathrm{~cm} \mathrm{dbh}$} \\
\hline $\mathrm{Sa} 02$ & 7 & 2.0 & 0.53 & 0.52 & -0.04 & 1 & $-0.029(0.0042)$ & 0.027 \\
\hline Sa05 & 8 & 3.9 & 0.72 & 0.73 & -0.01 & 1 & 0.029 (0.0175) & NS \\
\hline Sa06 & 5 & 1.4 & 0.20 & 0.32 & 0.31 & 1 & $0.252(0.0029)$ & 0.014 \\
\hline Sa27 & 11 & 6.6 & 0.72 & 0.84 & 0.04 & 1 & $0.153(0.0006)$ & 0.000 \\
\hline Sa29 & 7 & 1.9 & 0.28 & 0.41 & 0.13 & 1 & $0.416(0.0000)$ & 0.000 \\
\hline All loci & 7.6 & 3.16 & 0.502 & 0.564 & 0.086 & 5 & 0.164 & $<0.000$ \\
\hline \multicolumn{9}{|l|}{$1-10 \mathrm{~cm} \mathrm{dbh}$} \\
\hline $\mathrm{Sa} 02$ & 4 & 2.0 & 0.53 & 0.51 & -0.02 & 0 & $-0.022(-0.0600)$ & NS \\
\hline Sa05 & 8 & 3.9 & 0.74 & 0.74 & 0.01 & 1 & $0.005(0.0172)$ & NS \\
\hline Sa06 & 8 & 1.5 & 0.15 & 0.27 & 0.13 & 0 & $0.527(0.0000)$ & 0.000 \\
\hline Sa27 & 13 & 6.2 & 0.83 & 0.85 & 0.08 & 2 & $0.011(0.0279)$ & NS \\
\hline Sa29 & 8 & 1.7 & 0.37 & 0.48 & 0.26 & 1 & $0.107(0.0075)$ & 0.020 \\
\hline All loci & 8.2 & 3.06 & 0.524 & 0.556 & 0.092 & 4 & 0.118 & $<0.000$ \\
\hline \multicolumn{9}{|l|}{$>10 \mathrm{~cm} \mathrm{dbh}$} \\
\hline $\mathrm{Sa} 02$ & 6 & 2.3 & 0.60 & 0.56 & -0.05 & 0 & $-0.076(0.0130)$ & NS \\
\hline Sa05 & 7 & 3.5 & 0.78 & 0.71 & -0.05 & 0 & $-0.097(0.0061)$ & 0.038 \\
\hline Sa06 & 10 & 1.6 & 0.15 & 0.36 & 0.43 & 2 & $0.588(0.0000)$ & 0.000 \\
\hline $\mathrm{Sa} 27$ & 11 & 6.3 & 0.75 & 0.84 & 0.05 & 1 & $0.118(0.0031)$ & 0.003 \\
\hline Sa29 & 7 & 1.5 & 0.32 & 0.34 & 0.04 & 0 & $0.072(0.0177)$ & NS \\
\hline All loci & 8.2 & 3.04 & 0.520 & 0.562 & 0.084 & 3 & 0.121 & $<0.000$ \\
\hline
\end{tabular}

The number of private alleles (PA) at each locus is also given. $F_{\text {is }}$ (standard error) and departure from Hardy-Weinberg equilibrium was tested using Haldane's (1954) exact test and $P$-values were estimated (NS: $P>0.05$ ). Mean number of alleles per locus $=10.0$ across all three cohorts. Each cohort estimate is based on a sample of 100 individuals. 

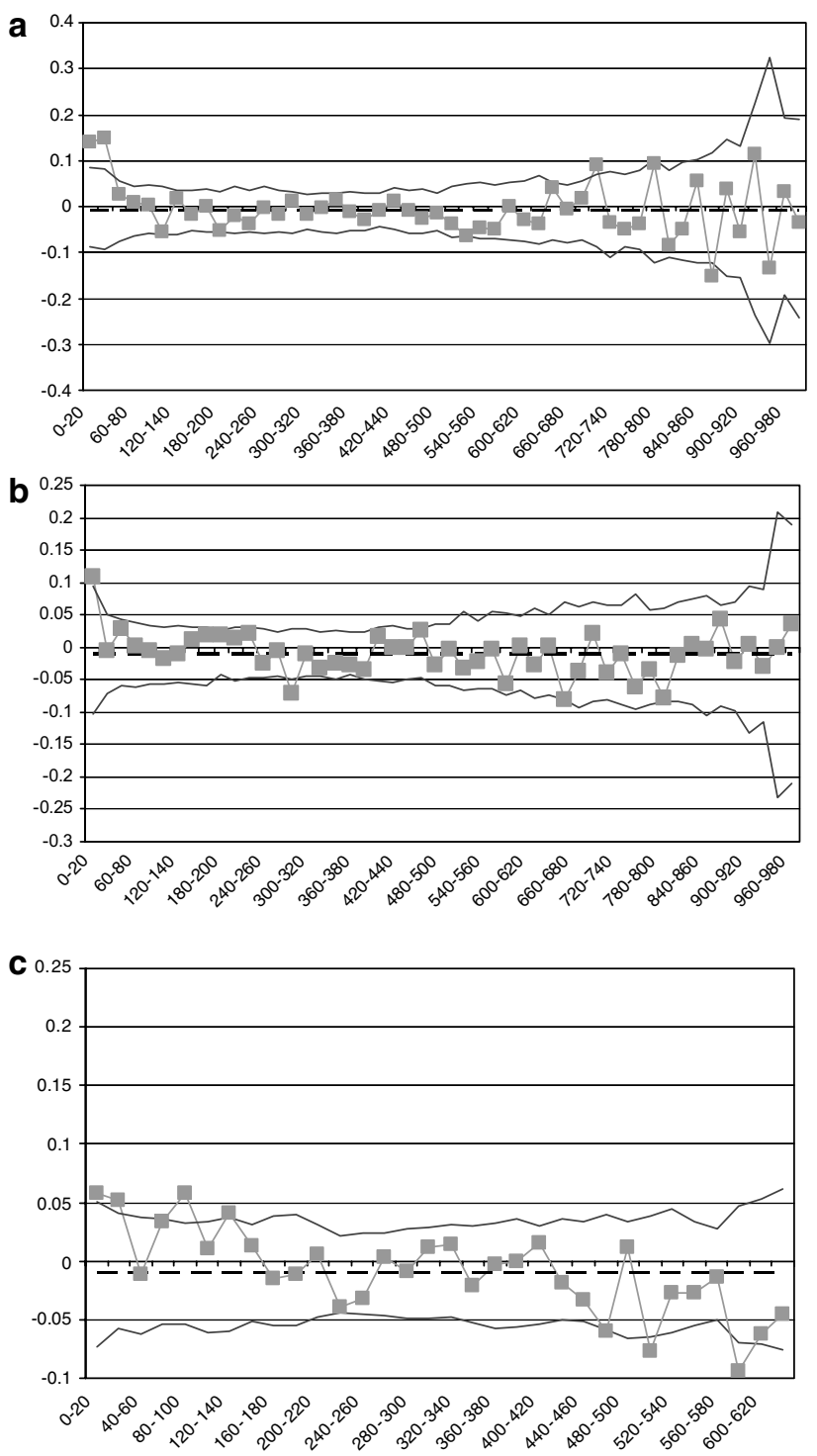

Figure 2 Correlogram of microsatellite data using Moran's Index to depict genetic spatial autocorrelation for 100 randomly selected $S$. amara in the 50 ha FDP representing three size categories at $20 \mathrm{~m}$ distance classes: $>10 \mathrm{~cm}$ dbh (a), $1-10 \mathrm{~cm} \mathrm{dbh}($ b) and $<1 \mathrm{~cm} \mathrm{dbh}$ (c). The reference lines around the point estimates represent $95 \%$ confidence intervals.

for the same classes failed to detect significant spatial autocorrelation at the same distances (Figure $3 a$ and $b$ ). The 100 seedlings $<1 \mathrm{~cm} \mathrm{dbh}$ exhibited significant genetic structure at distance classes of $0-40,80-100$, and $120-140 \mathrm{~m}$ using microsatellites. We observed a negative autocorrelation at distances between 480 and $540 \mathrm{~m}$ (Figure 2c).

Aggregation index values of $0.988,0.982$, and 0.635 for the $>10,1-10$, and $<1 \mathrm{~cm} \mathrm{dbh}$ cohorts, respectively, indicate that only at the seedling cohort are individuals more aggregated than would be expected at random. The mean distance to the nearest individual for the $>10,1-10$, and the $<1 \mathrm{~cm} \mathrm{dbh}$ cohorts is $34.1,34.1$, and $21.3 \mathrm{~m}$, respectively. Combining the largest two size classes reduces the mean distance between nearest individuals to $23.5 \mathrm{~m}$, though spatial aggregation remains nonsignificant.
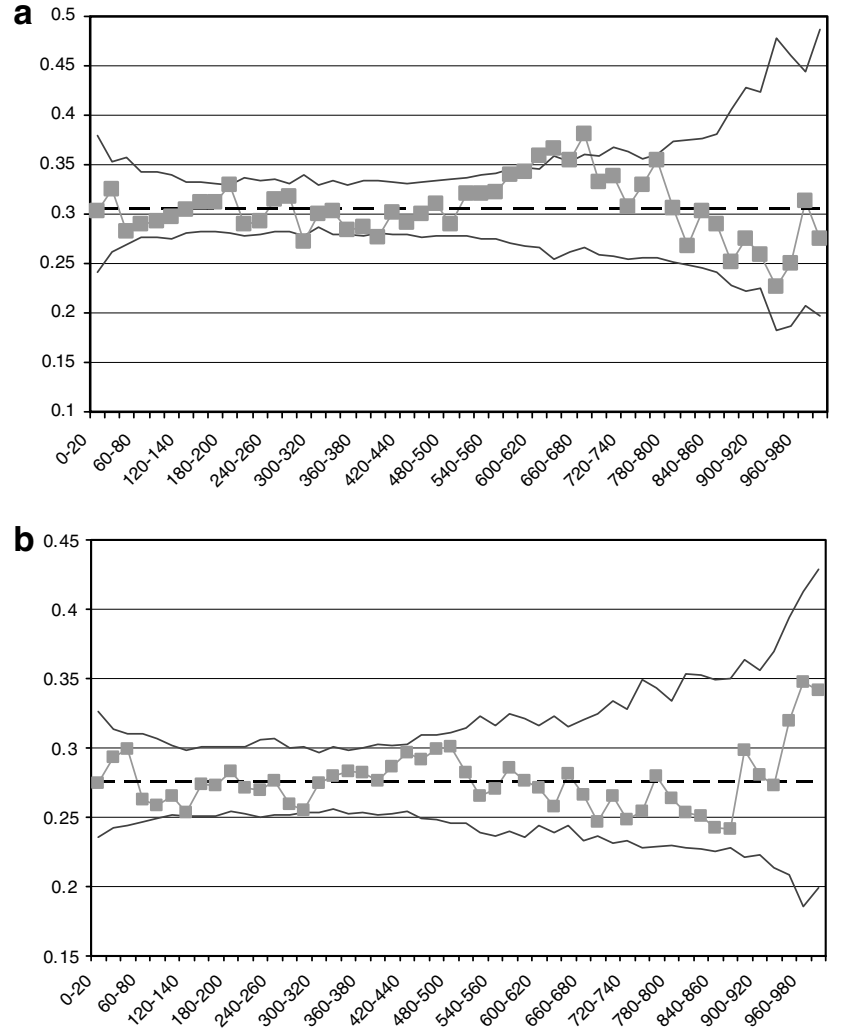

Figure 3 Distogram of AFLP data using Tanimoto Distance to spatial autocorrelation for $S$. amara individuals in two size categories at $20 \mathrm{~m}$ distance classes within the 50 ha FDP: $>10 \mathrm{~cm} \mathrm{dbh}(\mathbf{a})$ and $1-10 \mathrm{~cm} \mathrm{dbh}(\mathbf{b})$. The reference lines around the point estimates represent $95 \%$ confidence intervals.

\section{Discussion}

Theoretical models predict the existence of local spatial genetic structure under locally restricted gene flow (Wright, 1943, 1978), and an absence of spatial structure when gene flow via seeds is extensive. Where seed dispersal is limited, we expect to observe increased relatedness at decreasing spatial scales, particularly in plant populations with low densities of reproductive adults (Loiselle et al, 1995; Peakall and Beattie, 1995; Schnabel et al, 1998), as is generally found in tropical rain forest trees (Hubbell and Foster, 1983). Even with random mating, patches of highly related individuals (half siblings) will result in local spatial genetic structure (Vekemans and Hardy, 2004). Widespread seed dispersal and large neighborhood size or overlapping seed shadows can erase the spatial genetic structure, however, even if pollen flow is restricted (Hamrick and Loveless, 1986; Kalisz et al, 2001).

In comparing AFLP and microsatellite utility in this study, the two marker systems failed to yield identical results at each distance category. In fact, the AFLP analyses failed to find significant spatial autocorrelation, though it was detected using microsatellites in all three cohorts. There has been some difference of opinion regarding the relative usefulness of AFLPs and microsatellites (summarized in Campbell et al, 2003). We found that microsatellite markers demonstrated significant 
results in some instances where AFLP marker results were not significant, in spite of using a sizeable number of AFLP bands for analysis. This difference may be due to the fact that microsatellite markers are codominant and thus are more informative in this study than were the dominant AFLP markers. In further discussion we refer specifically to microsatellite findings.

We suggest that localized seed fall from related individuals accounts for the spatial genetic structure detected at the shortest distance categories for S. amara. The genetic structure pattern we observed at longer distance classes (between 480 and $600 \mathrm{~m}$ ) for the $<1 \mathrm{~cm}$ dbh category results from nearby individuals being more closely related than randomly selected individuals in the population. At further distances, other 'families' of trees are encountered, resulting in negative autocorrelation, as fewer alleles are shared than expected by chance. Perhaps, the lack of relatedness we detected at longer distance classes reflects long-distance dispersal events, which have resulted in the recruitment and persistence of individuals unrelated to their neighbors.

The spatial scale of genetic autocorrelation declines from the $<1 \mathrm{cmdbh}$ size class to the $1-10$ and $>10 \mathrm{~cm}$ dbh classes, suggesting that demographic thinning may be occurring between seed deposition, seedling establishment, and recruitment to later life history stages. The mean minimum distance between seedlings is less than that of older individuals: $21.3 \mathrm{~m}$ (range $=$ 0.9-1003.5 m), compared to $34.1 \mathrm{~m}$ (range $=3.3-1006.1 \mathrm{~m}$ ) and $34.1 \mathrm{~m} \quad($ range $=1.3-1012.8 \mathrm{~m}$ ) for $1-10$ and $>10 \mathrm{~cm}$ dbh trees, respectively. Also, since our relatedness values for the larger two size classes does not exceed 1.2 and for $<1 \mathrm{~cm} \mathrm{dbh}$ individuals relatedness is even less, it seems likely that some overlapping of seed shadows is present, even at the short distances.

Data from the FDP censuses intervals provide further evidence of demographic thinning in S. amara. Only 438 of the 1239 stems from the 1982 census were alive in the 2000 census, with the highest mortality occurring at the smallest (1-2 cm dbh) size classes. For example, between the 1995 and 2000 censuses, $1371-2 \mathrm{~cm}$ dbh individuals $(37 \%)$ died, whereas $62(16 \%)$ of the 371 trees that died were $\geqslant 10 \mathrm{~cm} \mathrm{dbh}$. Such thinning may contribute to the decay of spatial genetic structure through the culling of half-sibs in aggregations, or selection against inbred individuals. Selection against homozygotes is suggested by the slight decrease in $F_{\text {is }}$ from the $<1 \mathrm{~cm} \mathrm{dbh}$ individuals to the larger size classes, a pattern that has been reported for other tropical trees (eg AlvarezBuylla et al, 1996; Hufford and Hamrick, 2003). We found that overall levels of heterozygosity at all five loci were remarkably consistent among the three cohorts.

Muller-Landau (2001) estimated a mean dispersal distance of $39 \mathrm{~m}$ for $S$. amara from seed trap data, only slightly less than the mean minimum distance, $43.6 \mathrm{~m}$, between any two of the 48 female trees that have been reproductive during the last 3 years. Nonetheless, the generally low density of $>20 \mathrm{~cm}$ dbh $S$. amara on the FDP (2.4 trees perha ${ }^{-1}$ ) suggests that overlapping seed shadows are unlikely to be sufficiently pronounced to result in a mixture of different single tree progenies that might obscure weak spatial structure, and our finding of genetic autocorrelation at short distances in all age classes support this. With an estimated mean dispersal distance of nearly $40 \mathrm{~m}$, one would expect to observe at least some weak spatial genetic structure in S. amara at distances less than $100 \mathrm{~m}$ if the seed dispersal models utilized by Muller-Landau (2001) are accurate. We do observe structure at shorter distance classes for all three cohorts, providing support for these models. Current modeling techniques, however, likely underestimate seed dispersal distances because they assume seeds in traps arrive from the nearest adult tree. Models also fail to adequately account for long-distance seed input that may play a substantial role in spatial genetic processes (Oddou-Muratorio et al, 2001), as well as individual variability in fecundity and survivorship (Godoy and Jordano, 2001). Perhaps most importantly for the present study, the current models fail to incorporate dioecy and thus underestimate seed dispersal because any reproductive size adult is considered a potential seed donor.

Our study contributes to a growing database on patterns of spatial genetic structure at the stand level ( $\sim 1$ ha to several kilometers) for vertebrate-dispersed tropical tree species (eg Degen et al, 2001a; Dutech et al, 2002). Our experimental design is comparable to that of Degen et al (2001a), who analyzed spatial genetic structure using RAPD markers for eight canopy tree species in French Guiana using $150 \mathrm{~m}$ distance categories. They used the same randomized sampling strategy, but only considered trees $>10 \mathrm{~cm} \mathrm{dbh}$. Four of the animal dispersed species in their study showed no evidence of spatial genetic structure, although the other four species did exhibit significant spatial autocorrelations. Weak spatial genetic structure for both adults and seedlings was also observed within a large population of the vertebrate-dispersed tree, Carapa procera, in French Guiana (Doligez and Joly, 1997), though data were analyzed at the scale of hundreds of meter distance classes. Fine scale genetic structure, even at the shortest $(\leqslant 13 \mathrm{~m})$ distance class, was described as 'weak at most' by Chung et al (2000) in all five age classes of a birddispersed dioecious tree in southern Korea. Their focal area, however, was restricted to a very small $\left(60 \times 100 \mathrm{~m}^{2}\right)$ plot.

Hamrick et al (1993) found that two wind-dispersed species exhibited spatial genetic structure to $30 \mathrm{~m}$ (Alseis blackiana) and $100 \mathrm{~m}$ (Platypodium elegans) on BCI, though only in the $<1.0 \mathrm{~m}$ tall and $1-10 \mathrm{~cm}$ 'sapling' size classes; structure was not evident among the $>10 \mathrm{~cm}$ dbh cohort. Similarly, in a recent study by Latouche-Hallé et al (2003), significant positive spatial correlation was detected for the wind-dispersed tree Dicorynia guianensis for saplings and adults from 50 to ca. $125 \mathrm{~m}$ and a negative association was observed for adults from 200 to $300 \mathrm{~m}$, analyzed at $50 \mathrm{~m}$ distance intervals.

The variety of seed and pollen dispersal syndromes among tropical trees and the effectiveness of different dispersal vectors make broad-scale generalizations difficult, particularly in highly diverse tropical ecosystems. However, molecular approaches provide useful tools for assessing both seed arrival and effective dispersal in ways that traditional ecological studies cannot. Additional studies at multiple spatial and temporal scales will help improve our knowledge of the mechanisms and impacts of dispersal at both local and large scales. 


\section{Acknowledgements}

This research is part of a collaborative effort between the Smithsonian Tropical Research Institute in Panama and the SILVOLAB Guyane and INRA Station de Recherché Forestieres lab in France. This work received principal financial support from the Mellon Foundation, and supplementary support from the National Science Foundation and the International Plant Genetic Resource Institute (IPGRI). A Sigma Xi Grant-in-Aid of Research provided BDH support for $S$. amara collections. We thank $\mathrm{K}$ Peterson and P Ramos for field assistance, M Gonzales and O Sanjur for assistance in the laboratory, B Degen for improvements to the SGS software program, and S Lao for preparing the map in Figure 1. We also thank $O$ Calderon, SJ Wright and the Environmental Sciences Program of the Smithsonian Institution for seed trap data. Insightful comments from J Hamrick and two anonymous reviewers greatly improved this manuscript.

\section{References}

Aldrich PR, Hamrick JL (1998). Reproductive dominance of pasture trees in a fragmented tropical forest mosaic. Science 281: 103-105.

Alvarez-Buylla ER, Garcia-Barrios R, Lara-Moreno C, MartinezRamos M (1996). Demographic and genetic models in conservation biology: applications and perspectives for tropical rain forest tree species. Annu Rev Ecol Systematics 27: 387-421.

Bawa KS (1990). Plant-pollinator interactions in tropical rain forests. Annu Rev Ecol Systematics 21: 399-422.

Boshier DH, Chase MR, Bawa KS (1995). Population genetics of Cordia alliodora (Boraginaceae), a Neotropical tree. 3. Gene flow, neighborhood and population substructure. Am J Bot 82: 484-490.

Campbell D, Duchesne P, Bernatchez L (2003). AFLP utility for population assignment studies: analytical and empirical comparison with microsatellites. Mol Ecol 12: 1979-1991.

Chung MG, Chung MY, Oh GS, Epperson BK (2000). Spatial genetic structure in a Neolitsea sericea population (Lauraceae). Heredity 85: 490-497.

Condit R, Ashton PS, Baker P, Bunyavejchewin SS, Gunatilleke S, Gunatilleke N, Hubbell SP (2000). Spatial patterns in the distribution of tropical tree species. Science 288: 1414-1418.

Croat T (1978). Flora of Barro Colorado Island. Stanford University: California.

Degen B (1999). CoTrix-software for inheritance analysis. In: HEM Gillet (ed) Which Marker for Which Purpose?. Max Wiedebusch Kommiss.-Verl.: Hamburg, 2000, pp 155-156 Hamburg, Nr. 198. User's Manual. http://kourou.cirad.fr/ genetique/software.html\#CoTrix.

Degen B, Caron H, Bandou E, Maggia L, Chevallier $\mathrm{MH}$, Leveau A, Kremer A (2001a). Fine-scale spatial genetic structure of eight tropical tree species as analysed by RAPDs. Heredity 87: 497-507.

Degen B, Petit R, Kremer A (2001b). SGS - Spatial Genetic Software: a computer program for analysis of spatial genetic and phenotypic structures of individuals and populations. J Heredity 92: 447-448.

Dick CW, Etchelecu G, Austerlitz F (2003). Pollen dispersal of tropical trees (Dinizia excelsa: Fabaceae) by native insects and African honeybees in pristine and fragmented Amazonian rainforest. Mol Ecol 12: 753-765.

Doligez A, Joly HI (1997). Genetic diversity and spatial structure within a natural stand of a Neotropical forest tree species, Carapa procera (Meliaceae), in a French Guiana. Heredity 79: 72-82.
Dutech C, Seiter J, Petronelli P, Joly HI, Jarne P (2002). Evidence of low gene flow in a Neotropical clustered tree species in two rainforest stands of French Guiana. Mol Ecol 11: 725-738.

Gadeul M, Taberlet P, Till-Bottraud I (2000). Genetic diversity in an endangered alpine plant, Eryngium alpinum L. (Apiaceae), inferred from amplified fragment length polymorphism markers. Mol Ecol 9: 1625-1637.

Godoy JA, Jordano P (2001). Seed dispersal by animals: exact identification of source trees with endocarp DNA microsatellites. Mol Ecol 10: 2275-2283.

Gregorius HR (1978). The concept of genetic diversity and its formal relationship to heterozygosity and genetic distance. Math Biosci 41: 253-271.

Haldane JBS (1954). An exact test for randomness of mating. J Genet 52: 631-635.

Hamilton MB, Miller JR (2002). Comparing relative rates of pollen and seed gene flow in the island model using nuclear and organelle measures of population structure. Genetics 162: 1897-1909.

Hamrick JL, Loveless MD (1986). The influence of seed dispersal mechanisms on the genetic structure of plant populations. In: Estrada A, Fleming $\mathrm{T}$ (eds) Frugivores and Seed dispersal. Dr W Junk Publishers: Dordrecht, Netherlands. pp 211-223.

Hamrick JL, Murawski DA, Nason JD (1993). The influence of seed dispersal mechanisms on the genetic structure of tropical tree populations. Vegetatio 107/108: 281-297.

Hladik A, Hladik CM (1969). Rapports trophiques entre végétation et primates dans le foret de Barro Colorado (Panama). La Terre et la Vie 1: 25-117.

Howe HF (1986). Seed dispersal by fruit-eating birds and mammals. In: DR Murray (ed) Seed Dispersal. Academic Press: Sydney, Australia. pp 123-189.

Hubbell SP (1979). Tree dispersion, abundance, and diversity in a dry tropical forest. Science 203: 1299-1309.

Hubbell SP, Foster RB (1983). Diversity of canopy trees in a Neotropical forest and implications for conservation. In: Sutten SL, Whitmore TC, Chadwick AC (eds) Tropical Rain Forest: Ecology and Management. Blackwell Scientific Publications: Oxford.

Hufford KM, Hamrick JL (2003). Viability selection at three early life stages of the tropical tree Platypodium elegans (Fabaceae, Papilionoideae). Evolution 57: 518-526.

Jordano P, Godoy JA (2002). Frugivore-generated seed shadows: a landscape view of demographic and genetic effects. In: DJ Levey, W Silva, M Galetti (eds) Frugivores and Seed Dispersal: Ecological, Evolutionary, and Conservation Issues. CAB International: Wallingford, UK. pp 305-321.

Kalisz S, Nason JD, Hanzawa FM, Tonsor SJ (2001). Spatial population genetic structure in Trillium grandiflorum: the roles of dispersal, mating history, and selection. Evolution 55: 1560-1568.

Latouche-Hallé C, Ramboer A, Bandou E, Caron H, Kremer A (2003). Nuclear and chloroplast genetic structure indicate fine scale spatial dynamics in a Neotropical tree population. Heredity 91: 181-190.

Legendre P, Fortin M-J (1989). Spatial pattern and ecological analysis. Vegetatio 83: 107-138.

Leigh E (1982) In: Rand AS, Windsor DM, Leigh Jr EG (eds) The Ecology of a Tropical Forest: Seasonal Rhythms and Long-term Changes. Smithsonian Institution Press: Washington, DC.

Loiselle BA, Sork VL, Nason J, Graham C (1995). Spatial genetic structure of a tropical understory shrub, Psychotria officinalis (Rubiaceae). Am J Bot 82: 1420-1425.

Manly BFJ (1997). Randomization, Bootstrap and Monte Carlo Methods in Biology. Chapman \& Hall: London.

Marshall TC, Slate J, Kruuk LEB, Pemberton ZJM (1998). Statistical confidence for likelihood-based paternity inference in natural populations. Mol Ecol 7: 639-655.

Muller-Landau HC (2001). Seed dispersal in a tropical forest: empirical patterns, their origins, and their consequences for 
community dynamics. PhD Diss., Princeton University, Princeton, NJ.

Nason JD, Hamrick JL (1997). Reproductive and genetic consequences off forest fragmentation: two case studies of Neotropical canopy trees. J Hered 88: 264-276.

Oddou-Muratorio S, Petit RJ, Leguerroue B, Guesnet D, Demesure B (2001). Pollen- versus seed-mediated gene flow in a scattered forest tree species. Evolution 55: 1123-1135.

Ouborg NJ, Piquot Y, van Groenendael JM (1999). Population genetics, molecular markers and the study of dispersal in plants. J Ecol 87: 551-568.

Peakall R, Beattie AJ (1995). Does ant dispersal of seeds in Sclerolaena diacantha (Chenopodiaceae) generate local spatial genetic structure? Heredity 75: 351-361.

Raymond M, Rousset F (1995). Genepop (version 1.2): population genetics software for exact tests and ecumenicism. I Heredity 86: 248-249.

Ripley BD (1981). Spatial Statistics. Wiley Series in Probability and Mathematical Statistics. Wiley: New York.

Rodriguez von Platen H (2000). Genetic diversity of the tropical tree Simarouba amara in fragmented forests in Costa Rica as measured by DNA microsatellites. PhD Dissertation, Yale University.

Rodriguez von Platen H, Geistlinger J, Berlyn G, Kahl G, Weising K (2000). Characterization of novel microsatellite loci isolated from the tropical dioecious tree Simarouba amara. Mol Ecol Primer Notes 9: 498-500.
Schnabel A, Nason JD, Hamrick JL (1998). Understanding the population genetic structure of Gleditsia triacanthos L.: seed dispersal and variation in female reproductive success. Mol Ecol 7: 819-832.

Schupp EW (1993). Quantity, quality, and the effectiveness of seed dispersal by animals. In: TH Fleming, A Estrada (eds) Frugivory and Seed Dispersal: Ecological and Evolutionary Aspects. Kluwer Academic Publishers: Dordrecht, Netherlands. pp 15-29.

Sezen UU, Chazdon RL, Holsinger KE (2005). Genetic consequences of tropical second-growth forest regeneration. Science 307: 891.

Sokal RR, Wartenberg DE (1983). A test of spatial autocorrelation analysis using an isolation-by-distance model. Genetics 105: 219-237.

Vekemans X, Hardy OJ (2004). New insights from fine-scale spatial genetic structure analyses in plant populations. Mol Ecol 13: 921-935.

Webb CJ, Bawa KS (1983). Pollen dispersal by hummingbirds and butterflies: a comparative study of two lowland tropical plants. Evolution 37: 1258-1270.

Weir BS, Cockerham CC (1984). Estimating f-statistics for the analysis of population structure. Evolution 38: 1358-1370.

Wright S (1943). Isolation by distance. Genetics 28: 114-138.

Wright S (1978). Evolution and the Genetics of Populations, Vol 4. Variability Within and Among Natural Populations. University of Chicago press: Chicago, IL. 